\title{
Sperm Depletion: A Cost for Single Mated Females of Podisus nigrispinus (Dallas, 1851) (Heteroptera: Pentatomidae)
}

\author{
Leandro Sousa-Souto ${ }^{1}$, Walter Santos Evangelista Júnior ${ }^{2 *}$, Eraldo Rodrigues Lima ${ }^{1}$, José \\ Cola Zanuncio ${ }^{1}$, and Marcy das Graças Fonseca ${ }^{1}$ \\ ${ }^{l}$ Departamento de Biologia Animal; Universidade Federal de Viçosa; wevangelista @ufpa.br; 36570-000; Viçosa - \\ $M G-$ Brasil. $^{2}$ Colegiado de Ciências Agrárias; Universidade Federal do Pará; Campus do Sul e Sudeste do Pará; \\ $P A$ - Brasil
}

\begin{abstract}
The aim of this work was to test if egg viability of polyandrous females was increased with increasing number of matings. Longevity and reproductive output of females of the predatory stinkbug Podisus nigrispinus that were allowed to mate for 0, 1, 2, 3 times or were in the continuous presence of the same male was evaluated. Polyandry resulted in diminished sperm depletion. Females that had mated three times or that were in continuous presence of a male produced more offspring than females that mated once or twice throughout their lifetime. There was a negative correlation of mating history on female longevity. Results indicated that remating, either with same male or with different males were crucial for maximization of the reproductive success of females.
\end{abstract}

Key words: Asopinae, multiple matings, reproductive success, biological control, mate choice

\section{INTRODUCTION}

In many insect species, females may deplete the sperm they stored after mating (Mangan, 1979; Lauer, 1996; Sakurai, 1998) and female receptivity to remating is influenced by the amount of stored sperm. Multiple mating, either with the same male or with different males (polyandry) in these species is commonly observed in the field as well as in the laboratory (Thornhill and Alcock, 1983; Arnqvist and Nilsson, 2000). One obvious benefit of multiple mating is the replenishment of sperm (Thornhill and Alcock, 1983), thus ensuring fertilization of all female eggs. There are also drawbacks, however, associated with multiple mating, such as an increased risk of predation because of higher exposition to predators during copulation, and an increased risk of parasite transmission (Daly, 1978; Dickinson, 1997). Despite the likely negative effects of remating, the benefits are considered to outweigh the drawbacks (Arnqvist and Nilsson, 2000). Drawbacks of remating have been reported for the predatory bug Podisus nigrispinus (Dallas, 1851) (Heteroptera: Pentatomidae), where multiple mating decreased female longevity (Torres et al., 1997). However, it was unclear if this decreased longevity was due to remating or due to the experimental design, because remating was performed after the each egg laying, causing more manipulative stress to the females.

\footnotetext{
${ }^{*}$ Author for correspondence
} 
Even when remating decreases longevity, the net benefit of remating may be positive. To test the hypothesis that polyandry increases the fertile period of females, the time of sperm depletion and female survivorship of female $P$. nigrispinus that were mated 1, 2 or 3 times before first egg laying or were continuously paired with the same male was compared.

\section{MATERIALS AND METHODS}

Second-instar nymphs of $P$. nigrispinus were kept in groups of $10 \mathrm{in}$ an organdie bag attached to an Eucalyptus urophylla tree. They were allowed to feed in the leaves and in two Tenebrio molitor L. (Coleoptera: Tenebrionidae) pupae every two days until adult emergence. This procedure was important to give adults more precocious than nymphs maintained exclusively with $T$. molitor pupae (Zanuncio et al. 2000). Newly hatched virgin adults were put in separate plastic containers $(500$ $\mathrm{ml}$ ) until sexual maturity (3-4 days after emergence) (Zanuncio et al., 1992). After this period, 15 females were allowed to mate by confining them in a plastic container $(500 \mathrm{ml})$ together with one virgin male and observing mating behavior. These females were thus mated one time within a period of $24 \mathrm{~h}$. Another group of once mated females $(\mathrm{n}=10)$ were confined for another $24 \mathrm{~h}$ period with a second virgin male immediately after the first mating, and a third group $(n=10)$ was allowed to mate for three times in a similar way, hence, spending three days with three different virgin males. Females almost always mated with the male offered and if not, the male was changed for another. In only one case, the female did not mate. A last group of females was kept in continuous presence of one single male throughout their lifespan $(n=7)$. A group of unmated females $(n=7)$ were used as control. Different numbers of replicates among mated females are due to an insufficient number of virgin males.

The bugs were kept at $25 \pm 2{ }^{\circ} \mathrm{C}, 12 \mathrm{~h}$ photophase and were supplied with two T. molitor pupae every two days. A glass tube $(\varnothing=5 \mathrm{~mm}, 2.5 \mathrm{ml})$ containing water, with the open end facing down and sealed with a moistened cotton padding, was inserted through an opening made in the lid of each container as a supply of water and to maintain humidity. The number of eggs produced per female was scored every day for their entire life span.
Egg viability was determined through the division of total number of nymphs by total number of eggs produced by each female. Fertility period was the period between the first and last day that at least one viable egg was laid. Both egg viability and fertile period were compared using ANOVA with a generalized linear model $(\mathrm{glm})$ because the different number of replicates among treatments (Crawley 2002). The significance among the different treatments was compared using $a$ posteriori contrasts (Crawley 2002). Five females that mated three times and four females with continuous male presence died before the onset of sperm depletion (infertile egg production), and then they were discarded from the evaluation of fertility period.

Female longevity in different treatments was compared using survival analysis (Hosmer and Lemeshow, 1999). This analysis allowed the use of data from replicates in which the 'event' (death) was not observed. These data was treated as censored data and survival analysis used the information contained in them.

\section{RESULTS AND DISCUSSION}

The female fertility period was different among treatments $(F=47.72, \mathrm{p}<0.01)$ (Table 1$)$. Females that mated once and twice had a similar "time of fertility", which differed from females that were mated three times or in continuous contact with the same male (Table 1). This was caused by the higher fertility in the treatment with female paired continuously, followed by three mated females, compared to the other treatments $(F=12.64, \mathrm{p}<0.01)($ Table 1$)$.

Around $50 \%$ of the females that mated once or twice produced egg masses that were completely infertile up to 40 days after the last mating, indicating the onset of sperm depletion.

Two females that had mated once and one that had mated twice laid no viable eggs throughout their lifetime. Unmated females had a higher longevity than mated females. Thus, compared to unmated females or that had mated once or twice, female longevity was reduced for three times mated females or those in continuous presence of a male $($ Chi-square $=16.94, \mathrm{p}<0.01)($ Fig. 1$)$. 
Table 1 - Egg viability and fertility time (mean \pm standard error) of Podisus nigrispinus females with different numbers of mating with different males or in continuous presence of the same male.

\begin{tabular}{lcc}
\hline \multicolumn{1}{c}{ Treatment $*$} & Egg viability $(\boldsymbol{\%})$ & Fertility period (days) \\
\hline Mated once & $0.32 \pm 0.05 \mathrm{a}$ & $37.85 \pm 7.26 \mathrm{a}$ \\
Mated twice & $0.33 \pm 0.07 \mathrm{a}$ & $33.56 \pm 6.83 \mathrm{a}$ \\
Three matings & $0.57 \pm 0.08 \mathrm{~b}$ & $52.33 \pm 9.61 \mathrm{~b}$ \\
Continuous presence of male & $0.81 \pm 0.08 \mathrm{c}$ & $76.33 \pm 1.17 \mathrm{c}$ \\
\hline
\end{tabular}

"Means followed by the same letter within a column are not different by a posteriori contrasts $(\alpha=0.05)$.

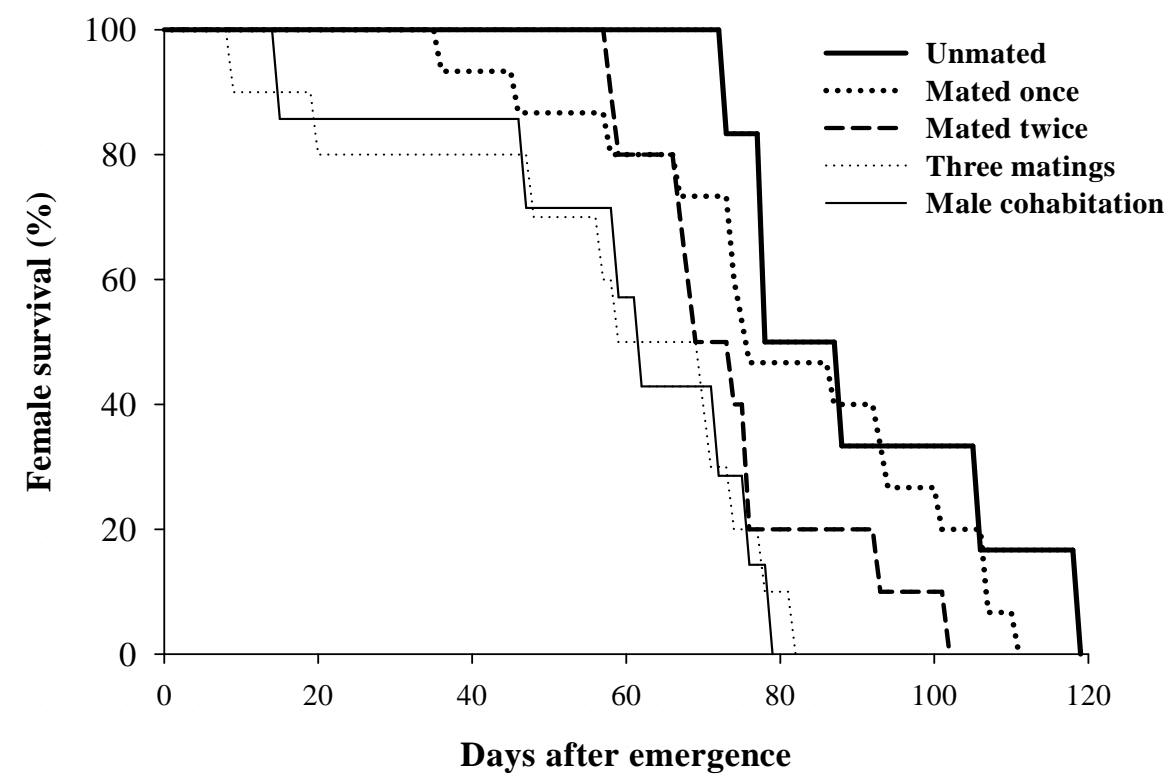

Figure 1 - Survivorship curves of unmated females, females that mated once, twice or three times, or could copulate at libitum. Compared to unmated females or that had mated once or twice (more than 100 days), female longevity was reduced for three times mated females or in continuous presence of a male (Chi-square $=16.94, \mathrm{p}<0.01)$.

Remating was important for reproductive success of $P$. nigrispinus females. The fact that two females that mated once and one female that mated twice did not produce viable eggs could be due to two possible factors: (i) no viable sperm was transferred during copulation; and (ii) sperm was ejected immediately following copulation. Sperm ejection is common in insects and it is an adaptive strategy in evolution of sexual conflict between male and female, where the female chooses which sperm will be allowed into the spermatheca (Thornhill and Alcock, 1983; Wedell et al., 2002). Sperm ejection in this study, however, was not evaluated; hence, further study would be needed to clarify its occurrence and importance in $P$. nigrispinus. The females that did not produce viable eggs might have done so because either no viable sperm was transferred or the male was infertile. Another hypothesis was that these females did not reach reproductive maturity even after four days of emergence.

Despite the short period to sperm depletion, females that mated once or twice had a lifetime fecundity similar to polyandrous females (Torres et al., 1997; Sakurai, 1998), indicating that these females were able to produce eggs even after sperm depletion and could remate with another males to preserve high fertility. The predatory stinkbug $P$. nigrispinus has been used in pest management programs to control lepidopterans defoliators in Eucalyptus spp. plantations (Zanuncio et al., 1994). Sperm depletion in females that mated once or twice indicated that remating was necessary to replenish inadequate 
sperm supply and thus achieve full fertility. Present results suggested that the effectiveness of release of females for biological control might be increased by allowing for at least three matings before release, or by releasing high numbers of males, to facilitate remating in the field.

\section{ACKNOWLEDGEMENTS}

The authors wish to thank to Arne Janssen (who received a scholarship as Visiting Teacher from CAPES, Brazil.) for helpful comments and English revision; Jorge Torres and José R. Gonçalves for their suggestions. Sousa-Souto L and Evangelista $\mathrm{Jr} \mathrm{W}$ were supported by $\mathrm{CNPq}$ scholarships.

\section{RESUMO}

Entre os heterópteros, o declínio da concentração de esperma pode ser um fator limitante para o sucesso reprodutivo desses insetos. Acasalamentos múltiplos conferem um reabastecimento de esperma e podem permitir um aumento do valor adaptativo das fêmeas. Neste estudo foi testada a hipótese de que a poliandria aumenta a viabilidade dos ovos. A longevidade de fêmeas de Podisus nigrispinus, bem como seus parâmetros reprodutivos em resposta a diferentes números de acasalamentos $(0,1,2,3$ ou em coabitação com o mesmo macho) foi avaliada. Esse percevejo vem sendo usado em programas de controle biológico de pragas em reflorestamentos de Eucalipto no Brasil. Apesar da diminuição no tempo de sobrevivência das fêmeas, acasalamentos múltiplos mantiveram a viabilidade dos ovos e o período reprodutivo das fêmeas, permitindo um maior número de descendentes produzidos. Tais resultados indicam que um número mínimo de três acasalamentos antes da primeira postura permite uma maximização do sucesso reprodutivo dessa espécie.

\section{REFERENCES}

Arnqvist, G. and Nilsson, T. (2000), The evolution of polyandry: multiple mating and female fitness in insects. Anim. Behav., 60, 145-164.
Crawley, M. J. (2002), Statistical Computing: An Introduction to Data Analysis using S-Plus. New York: John Wiley and Sons.

Daly, M. (1978), The cost of mating. Ame. Nat., 112, 771-774.

Dickinson, J. L. (1997), Multiple mating, sperm competition, and cryptic female choice in the leaf beetles (Coleoptera: Chrysomelidae). In: Choe, J. C. and Crespi, B. J. (Eds.). The Evolution of Mating Systems in Insects and Arachnids. Cambridge: Cambridge University. pp. 164-183.

Hosmer, D. W. J. and Lemeshow, S. (1999), Applied Survival Analysis. Regression Modeling of Time to Event Data. New York: John Wiley and Sons.

Lauer, M. J. (1996), Effect of sperm depletion and starvation on female mating behavior in the water strider, Aquarius remigis. Behav. Ecol. Sociob., 38, 89-96.

Mangan, R. L. (1979), Reprodutive behaviour of the cactus fly, Odontoloxozus longicornis: male territoriality and female guarding as adaptive strategies. Behav. Ecol. Sociob., 4, 265-278.

Sakurai, T. (1998), Variation in time to sperm depletion and oviposition patterns in females of Riptortus clavatus (Heteroptera: Alydidae). Ann. Entom. Soc. Am., 91, 737-740.

Thornhill, R. and Alcock, J. (1983), The Evolution of Insect Mating Systems. Cambridge: Harvard University.

Torres, J. B.; Zanuncio, J. C. and Oliveira, M. C. (1997), Mating frequency and its effect on female reproductive output in the stinkbug predator Podisus nigrispinus (Heteroptera: Pentatomidae). Med. Fac. Landbouww. Univ. Gent, 62, 491-498.

Wedell, N.; Gage, M. J. G. and Parker, G. A. (2002), Sperm competiton, male prudence and sperm-limited females. Trends Ecol. Evol., 17, 313-320.

Zanuncio, J. C.; Alves, J. B.; Zanuncio, T. V. and Garcia, J. F. (1994), Hemipterous predators of eucalypt defoliator caterpillars. Forest Ecol. Manag., 65, 65-73.

Zanuncio, J. C.; Didonet, J.; Santos, G. P. and Zanuncio, T. V. (1992), Determinação da idade ideal de acasalamento de fêmeas de Podisus connexivus Bergroth, 1891 (Hemíptera: Pentatomidae) visando uma criação massal. Rev. Árv., 16, 362-367.

Zanuncio, J. C.; Zanuncio, T. V.; Guedes, R. N. C. and Ramalho, F. S. (2000), Effect of feeding on three Eucalyptus species on the development of Brontocoris tabidus (Heteroptera: Pentatomidae) fed with Tenebrio molitor (Coleoptera: Tenebrionidae). Biocontr. Sci. Technol., 10, 443-450.
Received: July 19, 2005; Revised: November 09, 2005; Accepted: August 03, 2006. 